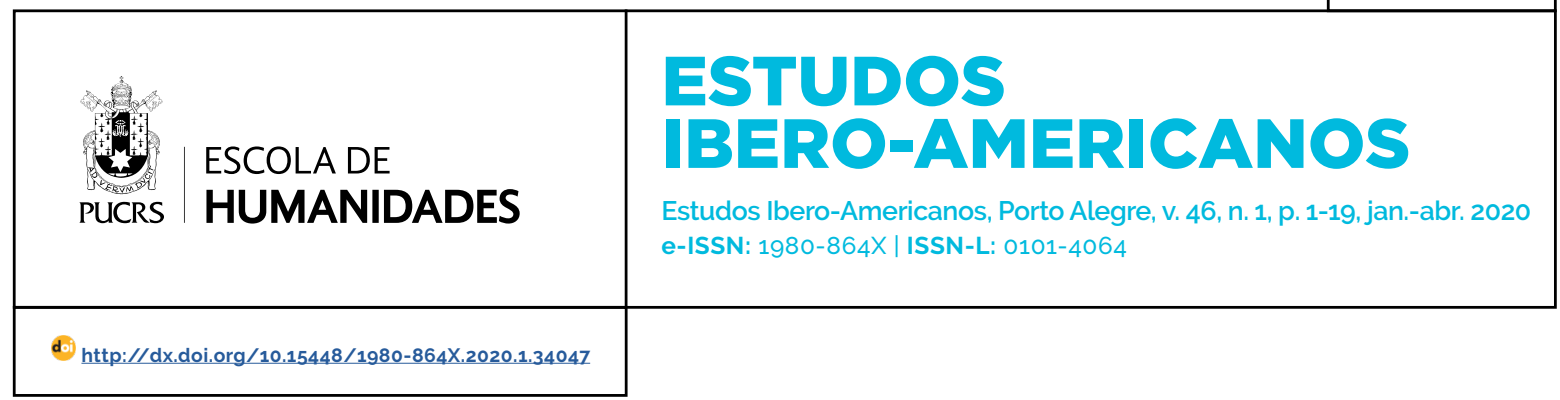

SEÇÃO: DOSSIÊ

\title{
A borracha que apaga o café: notas para uma história tecnoambiental da seringueira em São Paulo'
}

\author{
The rubber that erases the coffe: notes for a techno-environmental history of the rubber \\ tree in São Paulo \\ El caucho que borra el café: notas para una historia tecnoambiental de la seringueira \\ en São Paulo
}

\section{Eduardo Di Deus ${ }^{2}$}

orcid.org/0000-0001-9523-8844

eduardodideus@unb.br

Recebido em: 5 jul. 2019.

Aprovado em: 24 jul. 2019.

Publicado em: 28 abr. 2020
Resumo: O presente artigo tem como objetivo compreender a chegada e crescimento da cultura da seringueira (Hevea spp.) no estado de São Paulo, em especial, na região do interior paulista conhecida como planalto ocidental. Para entender como a seringueira chegou a vivenciar um boom nessa região a partir do final dos anos 1980 será preciso recuar algumas décadas e recuperar a história dessa importante espécie vegetal no estado mais industrializado do País. Isso será feito com uma abordagem que definimos como tecnoambiental, ou seja, que coloca em diálogo a história ambiental com os estudos antropológicos e históricos das técnicas.

Palavras-chave: Seringueira. História ambiental. Técnicas.

Abstract: The present article aims to understand the arrival and growth of the rubber tree (Hevea spp.) in the western plateau of the São Paulo state, Brazil. To understand how the rubber tree experienced a boom in this region from the end of the 1980's it will be necessary to go back few decades and recover the history of this important plant species in the most industrialized state of the country. This will be done with an approach defined as techno-environmental, that is, that puts in dialogue the environmental history with the anthropological and historical studies of the techniques.

Keywords: Rubber tree. Environmental history. Techniques.

Resumen: El presente artículo tiene como objetivo comprender la llegada y crecimiento de la cultura de la seringueira (Hevea spp.) en el estado de São Paulo, Brasil, en especial en la región del interior paulista conocida como meseta occidental. Para entender cómo la seringueira llegó a experimentar un boom en esta región a partir de finales de los años 1980 será necesario retroceder algunas décadas y recuperar la historia de este importante especie vegetal en el estado más industrializado del país. Esto se hará con un enfoque que definimos como tecnoambiental, es decir, que pone en diálogo la historia ambiental con los estudios antropológicos e históricos de las técnicas.

Palabras clave: Seringueira. Historia ambiental. Técnicas.

\section{(c) (1)}

Artigo está licenciado sob forma de uma licença Creative Commons Atribuição 4.0 Internacional.

\footnotetext{
1 Este artigo resulta de pesquisa de doutorado realizada no Laboratório de Antropologia da Ciência e da Técnica do Departamento de Antropologia da Universidade de Brasilia (LACT/DAN/UnB), financiada pelo Conselho Nacional de Desenvolvimento Científico e Tecnológico (CNPq) e pela Coordenação de Aperfeiçoamento de Pessoal de Nivel Superior (Capes-PDSE).

2 Universidade de Brasilia (UnB), Brasilia, DF, Brasil.
} 


\section{Introdução}

O presente artigo tem como objetivo compreender a chegada e crescimento da cultura da seringueira (Hevea spp.) no estado de São Paulo, em especial, na região do interior paulista conhecida como planalto ocidental. Para entender como a seringueira chegou a vivenciar um boom nessa região a partir do final dos anos 1980 será preciso recuar algumas décadas e recuperar a história dessa importante espécie vegetal no estado mais industrializado do País. Isso será feito com uma abordagem que definimos como tecnoambiental, ou seja, que coloca em diálogo a história ambiental com os estudos antropológicos e históricos das técnicas.

Nosso ponto de partida é uma obra que, segundo José Augusto Drummond (1991, p. 191), foi pioneira na história ambiental no Brasil: o primoroso A luta pela borracha no Brasil, de Warren Dean (1989), talvez a mais importante história da seringueira e da heveicultura no mundo. A conclusão do autor é a de que o principal responsável pela falha do Brasil em viabilizar plantações de seringueira produtivas teria sido um fungo causador do chamado maldas-folhas (Microcyclus ulei). Dean concluiu que "um fungo mudou a história de uma nação" (DEAN, 1989, p. 225), conjecturando em seguida qual não teria sido o impacto econômico e social da viabilização dos plantios da Hevea no Brasil ao longo do século XX. Curiosamente, no intervalo de dois anos entre a publicação original em inglês e a primeira edição em português o autor notou que algo havia mudado, tendo a área plantada com a espécie praticamente dobrado entre 1987 e 1989, pois "fazendeiros paulistas, desanimados com o café, a cana de açúcar e os citros, começaram a experimentar a Hevea" (DEAN, 1989, p. 235). Para compreender como, a partir de um quadro de derrota provocada por um fungo, segundo o decano da história ambiental no Brasil, chegou-se à afirmação de que "a seringueira agora é paulista" (SOMAIN; DROULERS, 2016, p. 1), recuaremos algumas décadas na reconstrução da história deste cultivo e traremos para o centro da análise as transformações nos modos de se relacionar com estas plantas para delas extrair o látex.

Tendo como inspiração o trabalho de Dean em um tipo de interface entre história ambiental e história da agricultura, buscarei fazer isso a partir de um diálogo com os estudos a respeito dos fenômenos da técnica. Buscarei recontar a chegada da seringueira no estado de São Paulo, complementando a obra de referência da história da heveicultura no Brasil, que acabou por se concentrar nos esforços feitos até a década de 1980 para viabilizar esta cultura em áreas úmidas da Amazônia e Mata Atlântica.

Em um plano mais específico, da história da heveicultura, pretendo chamar a atenção para um aspecto tratado como marginal: a sangria de seringueiras, no conjunto dos processos de extração da borracha como um todo. Em geral, esses aspectos foram relegados às notas de rodapé nessas histórias, dominadas pelas narrativas a respeito da viabilização dos plantios e melhoramento genético. Em um plano mais geral, defendo que o campo da história ambiental no Brasil tem a ganhar a partir de um diálogo com a história das técnicas. Nos termos de Donald Worster (1991), trata-se de escapar de uma ênfase muito grande no terceiro nivel de atuação a história ambiental, qual seja, o das ideias, representações e significados a respeito do ambiente e da natureza.

A coletânea organizada por Sautchuk (2017) indica tendência de crescimento de uma antropologia da técnica no Brasil, com inspiração no entendimento amplo e antropológico da técnica que permeia a tradição francesa, na qual a abordagem histórica (por vezes arqueológica) é parte do empreendimento antropológico. Autores como François Sigaut e André-Georges Haudricourt, historiador e agrônomo de formação, respectivamente, foram importantes alunos de Marcel Mauss que desenvolveram amplos estudos sobre a história e a antropologia da agricultura e da relação com os meios naturais, com foco nas tradições europeias e asiáticas.

Como a heveicultura não foi uma cultura que realizou a colonização do interior paulista, iniciaremos o artigo com uma breve incursão no 
processo de colonização da região, por meio da associação entre cafeicultura e avanço da malha ferroviária, na virada do século XIX para o XX. Veremos que desde esse tempo a seringueira e o café estiveram conectados em múltiplas escalas, que vão desde o local ao global. Em seguida, buscaremos recompor, com os elementos historiográficos que dispomos, o trajeto das primeiras incursões da seringueira no estado de São Paulo, bem como sua viabilização em plantios produtivos no planalto ocidental paulista.

Ao revisar uma rica e já bastante discutida história das diásporas globais da Hevea (DEAN, 1989), procuramos destacar que não só sementes, mudas e material botânico foram transportados, mas também conhecimentos e saber-fazer, relativos a um complexo de relações para dessas árvores extrair a borracha. Verdadeiros "sistemas técnicos" viajaram e se transformaram (DI DEUS, 2017). ${ }^{3}$ Neste artigo nosso olhar se volta ao processo de chegada das plantações de seringueira a São Paulo, em processos de reconversão de cultivos anteriores, como o café, os citros e a cana, como mais um episódio entre os inúmeros da diáspora global da heveicultura. Espero destacar a importância, para o campo da história ambiental, de um olhar antropológico e histórico para os processos técnicos, ao acompanharmos como a sangria da seringueira e os processos de extração como um todo, não obstante tenham sido destacados pelos próprios agentes dessa transferência para São Paulo como importantes, tenham sido quase sempre relegados a um aspecto marginal em relação à preocupação com o melhoramento genético, que dirigiu os esforços governamentais e dos agentes privados que atuaram neste processo.

\section{O café abre caminho no "sertão paulista"}

Para melhor compreender o surgimento da cultura da seringueira no interior paulista é importante, primeiramente, descrever como se deu a colonização da região. O avanço da cafeicultura, a partir das mais antigas zonas cafeeiras no Vale do Paraíba, em direção ao "oeste paulista", no sentido amplo, moldou não somente o seu meio rural, mas marcou profundamente a própria formação dessas regiões, na medida em que o café foi responsável pela frente pioneira que colonizou definitivamente esses territórios, na virada dos séculos XIX e XX. Esse oeste paulista histórico coincidia quase totalmente com mais da metade do território, o chamado planalto ocidental paulista (ROSS; MOROZ, 1997). Esse se localiza a oeste da região montanhosa que faz fronteira com Minas Gerais e a norte e a oeste das regiões de relevo acidentado em torno da capital São Paulo. Com exceção de áreas de colonização mais antigas próximas às cidades de Campinas e Botucatu, por exemplo, a maior parte do planalto foi considerado sertão paulista até ser colonizado definitivamente pelas frentes pioneiras do café. Tendo chegado ao estado por volta de 1840 no Vale do Paraíba, região limitrofe ao Rio de Janeiro, então principal produtor no Brasil, o café se expande progressivamente a oeste, estimulando e sendo estimulado pela extensão das linhas férreas que avançavam rumo ao sertão. Esse processo levou o planalto paulista a assumir, do final do século XIX à década de 1930, a liderança mundial na produção de café (MONBEIG, 1984; HOLLOWAY, 1984).

\footnotetext{
3 A pesquisa que origina este trabalho se baseia tanto em etnografia das práticas laborais de sangradores de seringueira em plantações no interior de São Paulo, quanto em pesquisa histórica sobre os modos de se relacionar com a Hevea. O trabalho etnográfico consistiu em observação e descrição do trabalho de sangradores em suas rotinas, tendo as tarefas de sangria como ponto de partida. No entanto, fui além da observação indireta do trabalho dos mesmos. Inseri-me como aprendiz do ofício de sangrador, recurso que, de acordo com Wacqüant (2002) e Sautchuk e Sautchuk (2014) amplia o potencial de acessar reflexões dos praticantes sobre suas atividades. Além disso, de forma a desenvolver os aspectos históricos deste estudo, realizei pesquisa em arquivos e bibliotecas importantes para a cultura da seringueira, entre os quais destaco: a biblioteca do Instituto Brasileiro de Meio Ambiente e Recursos Naturais Renováveis (IBAMA) em Brasília, onde se situa o acervo da extinta Superintendência da Borracha (SUDHEVEA); a biblioteca e o arquivo do Instituto Agronômico de Campinas (IAC); a biblioteca do Jardim Botânico do Rio de Janeiro; a Biblioteca Nacional do Rio de Janeiro; duas bibliotecas do Centre de coopération internationale en recherche agronomique pour le développement (CIRAD), em Montpellier e na região de Paris, França; e os arquivos históricos do Jardim Botânico de Kew, Inglaterra. No presente texto será privilegiado material oriundo da pesquisa em acervos documentais, embora ao final do artigo alguns elementos oriundos da pesquisa etnográfica sejam também mobilizados.
} 


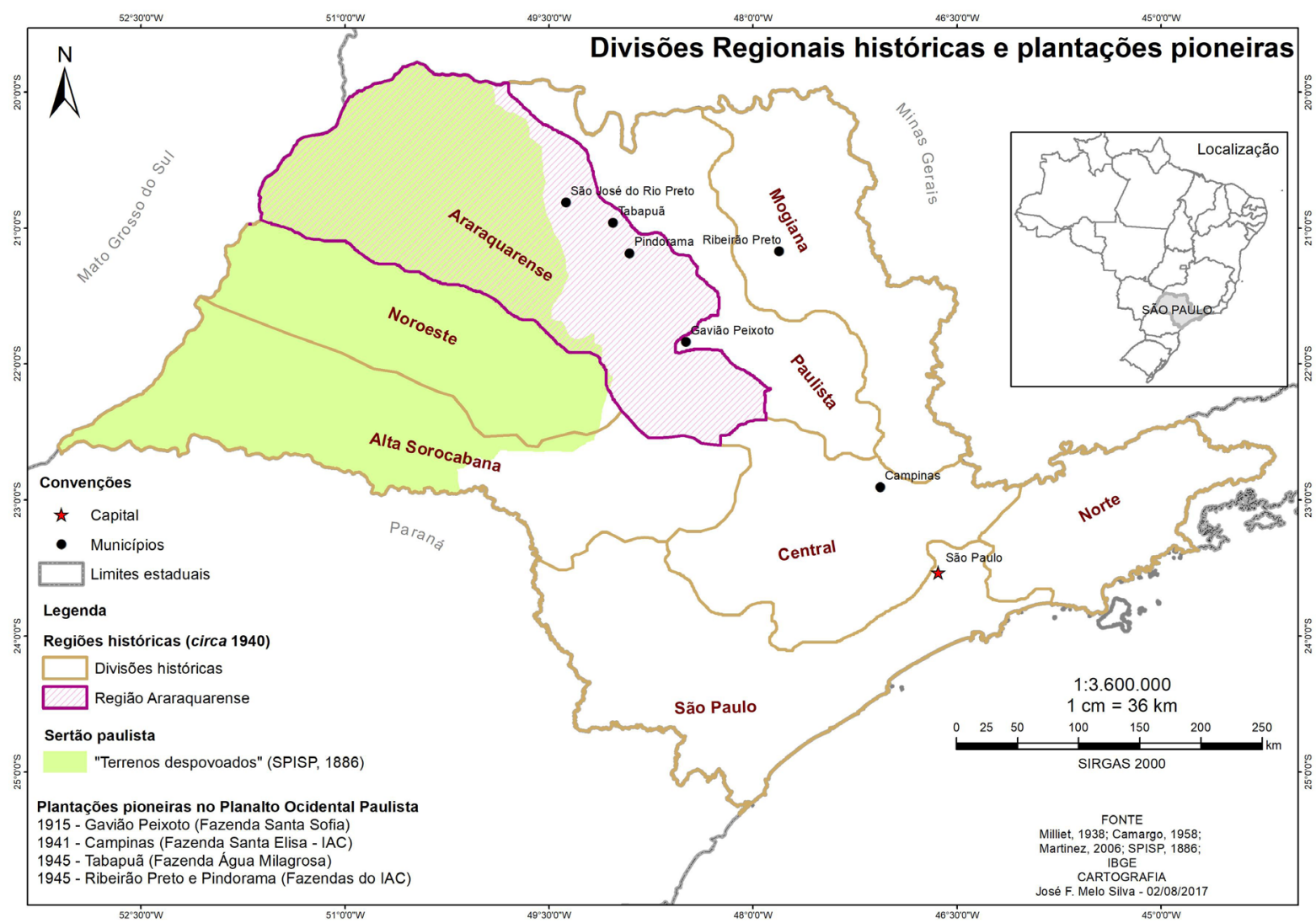

Figura 1 - Regiões históricas de São Paulo e plantações pioneiras de seringueira.

Fonte: Milliet (1941); Camargo (1958); Martinez (2006) e mapa da Sociedade Promotora de Immigração de São Paulo (SPISP, 1886).

Como demonstram estudos importantes (MARTINS, 2010; STOLCKE, 1986) a cafeicultura se constituiu como um sistema híbrido de relações capitalistas e não capitalistas, mas capitalista por essência em sua esfera comercial, como também era a indústria extrativista da borracha (ALMEIDA, 1992). Nesse plano comercial, o capital cafeicultor estava atrelado a outras atividades econômicas, como o investimento em indústrias e nas próprias estradas de ferro, a partir das quais se reproduzia. A cafeicultura passou a um rápido avanço ao planalto ocidental paulista, entre o final do século XIX e as primeiras décadas do $X X$, que atingiu a região que hoje conhecemos como noroeste paulista ${ }^{4}$, por meio da Estrada de Ferro Araraquarense, em um modelo peculiar. Diferente da primeira parte do Oeste a ser ocupado pelo café, nos férteis solos de Ribeirão
Preto, por exemplo, onde os trilhos chegaram pouco tempo após a abertura das fazendas, o contrário se deu nas regiões das ferrovias Araraquarense e Noroeste (que compreendem o atual noroeste paulista). Companhias que surgiam com o capital cafeeiro construiam as ferrovias e também loteavam as terras que viriam a ser novas fazendas de café, o que fez com que a cafeicultura tivesse um papel preponderante no nascimento ou crescimento exponencial de municípios, em uma verdadeira "sociedade em movimento" que avançava com suas "franjas pioneiras" (MONBEIG, 1984; MAHL, 2007, p. 19-73; MELO, 2013, p. 49-103)

Nesse "surto ferroviário" (MARTINS, 2010, p. 49) que conduzia uma "febril abertura de novas fazendas" (MARTINS, 2010, p. 61) foi que o noroeste paulista, a região de São José do Rio

4 Embora não seja uma nomenclatura regional oficial, noroeste paulista é uma expressão muito usada pelas pessoas que lá vivem e tem sido usada em estudos acadêmicos (Cf. MAHL, 2007: MELO, 2013). Engloba aproximadamente as Mesorregiões de São José do Rio Preto e Araçatuba, segundo critérios do Instituto Brasileiro de Geografia e Estatística (IBGE). 
Preto - antes caracterizada por um povoamento esparso - vivenciou um crescimento populacional e econômico. Essa área do sertão paulista não tinha sido efetivamente colonizada nos ciclos bandeirantes anteriores. Esse sertão era habitado originalmente por uma diversidade de povos indigenas, os "verdadeiros pioneiros" (MONBEIG, 1984, p. 129), que foram exterminados ou expulsos para outras regiões com o avanço dos colonizadores 5 . Os primeiros brancos a tentarem a ocupação desses territórios foram os "mineiros", que abriam as conhecidas estradas boiadeiras em busca de terra, fundavam vilas e se estabeleciam. Rio Preto foi fundada por esses "precursores", nos anos 1850, mas se manteve como uma pequena vila até ser alcançada pela frente pioneira cafeeira. A chegada dos trilhos da Estrada de Ferro Araraquarense à cidade em 1912 transformou Rio Preto em "boca de sertão" ou "ponta dos trilhos" (MAHL, 2007, p. 40-45; HOLLOWAY, 1984, p. 41). Rio Preto permaneceu nessa condição até 1933, quando a ferrovia Araraquarense avançou em direção a Mirassol, depois alcançou Votuporanga e em seguida a fronteira com o então estado de Mato Grosso, no Rio Paraná. Esses vinte anos como "ponta dos trilhos" foram fundamentais para seu crescimento e transformação em cidade polo da região que passou a ser uma das zonas fortes do café, com o plantio nas férteis áreas recentemente desmatadas. Hoje continua sendo cidade polo do chamado noroeste paulista, que é o maior centro produtor de borracha natural no Brasil, mas a produção de café é mínima.

É curioso notar que os dois principais produtos de exportação do Brasil naquela virada de século, café e borracha, geraram movimentos contemporâneos de ampliação de fronteiras. O café adentrava o sertão paulista e as frentes seringalistas subiam os rios da Amazônia. Fronteiras possibilitadas pelo avanço das ferrovias, na primeira, e dos barcos a vapor, na segunda ${ }^{6}$. Estes produtos de origem vegetal, borracha e café, já estavam interligados em um mercado global. No tempo em que a seringueira fora levada pelos ingleses para a Ásia, nos anos 1870, o noroeste paulista ainda era considerado sertão paulista. O sucesso da cafeicultura em seu primeiro avanço para o oeste, na região de Ribeirão Preto, foi fator decisivo para que os plantadores de café da península Malaia e Ceilão, desestimulados pela concorrência paulista na década de 1890, aceitassem investir naquela exótica árvore produtora de borracha7.

A cafeicultura que começava a avançar para o planalto paulista acabou por influenciar, desse modo, o surgimento da heveicultura asiática, cuja concorrência daria fim à hegemonia da indústria extrativista amazônica. Nessa espécie de influência cruzada em escala global, o tempo para as ferrovias e o café chegarem à Alta Araraquarense foi o prazo que a produção de borracha das plantações asiáticas levou para superar a produção nativa da Amazônia. Em 1911 a produção asiática de borracha superou a amazônica, quase simultaneamente à chegada dos trilhos da Estrada de Ferro Araraquarense à cidade que passou a ser conhecida como a capital da região Alta Araraquarense, Rio Preto, possibilitando o avanço da cafeicultura para a

\footnotetext{
5 Esse avanço pioneiro foi devastador também para o complexo ecossistema de transição entre floresta atlântica e cerrados que cobria a região, um conjunto de florestas com manchas de savanas e campos. A respeito deste ecossistema de transição, segundo Monbeig, "os desbravadores dos planaltos ocidentais paulistas comparam sua terra a uma pele de onça-pintada" (Ibid., p.75). O avanço da cafeicultura representou uma "devastação sem freio" (Monbeig, Ibid., p. 75) destas florestas, que neste processo de "desbravamento" era considerada "mais como uma dificuldade a superar do que como um recurso possivel" (Ibid., p. 247). Foi desta maneira que poucas áreas florestais restaram na região, apenas áreas de mata ciliar ou pequenas manchas nas fazendas, chamadas pelos seringueiros contemporâneos quase sempre de matinha.

6 Mahl (2007, p. 37) fala de uma "belle époque tardia" em Rio Preto nos anos 1920, como "ponta de trilhos"/ "boca de sertão", processo similar vivido em Manaus e, em certa medida, em Rio Branco e Xapuri, no apogeu da economia extrativista, na virada dos séculos XIX e XX. Assim como Xapuri era a "princesinha do Acre", Rio Preto era a "princesinha do sertão".

"A temporada 1887-1898 foi, de fato, o momento decisivo: uma queda acentuada no preço do café, acompanhada de um aumento acentuado do preço da borracha, convenceu os plantadores do Ceilão e da Malásia a redirecionarem seus recursos [...] A escolha da seringueira por parte dos plantadores orientais foi, até certo ponto, resultado da maior competitividade dos cafeicultores brasileiros. Só os brasileiros podiam lucrar diante da queda dos preços do café no final do século XIX. Os plantadores do Ceilão, portanto, tiveram de procurar um produto alternativo, e muitos escolheram a Hevea. A economia amazônica, por sua vez, foi arrasada pela concorrência do Ceilão e da Malásia" (DEAN, 1989, p. 60-65).
} 
região. Foi neste mesmo periodo, por volta de 1915. que a historiografia registra a chegada da seringueira ao planalto paulista.

\section{Os primórdios}

A história da borracha se inicia no estado de São Paulo, segundo a maioria dos relatos, com o então General Cândido Rondon, que enviou, por volta de 1915, da região que viria a ser o estado de Rondônia, as primeiras sementes para a fazenda Santa Sofia, em Gavião Peixoto, à época um distrito de Araraquara (CAMARGO, 1958; HOELZ, 1958; HOELZ; MARTINEZ, 1972; CARDOSO, 1976, 1979; CORTEZ, 1986; GONÇALVES, 2002; MARTINEZ, 2006). O agrônomo Felisberto Camargo, importante agente da heveicultura paulista e brasileira, assim narra o episódio:

Na obra de formação de seringais de cultura, aparece, em primeiro plano, a figura insigne do General Rondon, representante máximo da nossa civilização primitiva, trazendo do coração de Rondônia, e de dentro de seu próprio coração, um punhado de sementes da legitima Hevea brasiliensis e oferecendo-as ao seu amigo pessoal, Cel. Procópio Ferraz, fazendeiro de café em Gavião Peixoto, próximo à Araraquara. Num segundo plano, aparece a Fazenda de Café com sua organização, com suas armas de civilização e de conquista de nosso sertão (CAMARGO, 1960, p. 2).

Camargo explica como as duas culturas, da seringueira e do café, estiveram articuladas, não somente no plano do mercado global, como assinalamos acima, mas também no território paulista. O trecho citado faz parte de palestra proferida durante visita de membros da Escola Superior de Guerra à pioneira plantação de seringueiras no planalto ocidental paulista, localizada na Fazenda "Água Milagrosa", em Tabapuã-SP, cujas árvores foram plantadas nos anos 1940 com sementes vindas de Gavião Peixoto. Camargo integrava um esforço conjunto, por volta dos anos 1950 e 60, de fazendeiros pioneiros, pesquisadores e do governo do estado para promover a seringueira como cultivo a substituir áreas antigas do café. Esse esforço era estimulado também pela crescente indústria paulista de artefatos de borracha, preocupada com o início da importação de borracha em 1951.

Entretanto, antes de avançar neste ponto fazse necessário recuar um pouco para recompor a história da borracha em São Paulo. Em um tempo em que as sementes de seringueira levadas pelos britâncos Wickham e Cross ainda não haviam chegado à Ásia, o engenheiro Silva Coutinho já propunha "acclimar-se na parte inferior do Valle do Ribeira o cacoeiro e a sinphonea elastica lantigo nome científico da seringueiral" (COUTINHO, 1872, p. 15). Fez tal proposta em relatório no qual estudava as melhores rotas para a construção de vias férreas entre o litoral e a comarca de Botucatu ${ }^{8}$, preconizando e prenunciando o plantio da Hevea no litoral sul paulista. Nove anos antes o mesmo Silva Coutinho havia sugerido, também de forma pioneira, em viagem à Amazônia, o plantio dessa espécie na própria região (COUTINHO, 1863).

A proposta de Coutinho é contemporânea do esforço das metrópoles europeias para transferir plantas produtoras de borracha para suas colônias tropicais (DI DEUS, 2017). Naquele contexto, as primeiras plantas laticiferas ${ }^{9}$ efetivamente exploradas em São Paulo foram a mangabeira (Hancornia speciosa), espécie nativa também nos cerrados e campos do planalto ocidental paulista, e a maniçoba (Manihot spp.), com sementes vindas do Ceará em 1899, experimentadas pelo Instituto Agronômico de Campinas em ensaios consorciados com o café, durante uma crise desta cultura. Nos arquivos do Kew Gardens, nos arredores de Londres, há um conjunto de relatórios e correspondências escritos por diplomatas americanos em Santos, Campinas e Pernambuco que tratavam, entre os

8 Essa comarca abrangia à época parte significativa do interior paulista a oeste e norte, dando a dimensão da diminuta ocupação do planalto paulista antes do avanço do café e das ferrovias.

9 Plantas laticiferas são aquelas que possuem estruturas capazes de produzir o látex, líquido espesso geralmente de coloração entre o branco e o amarelado. De composição e funções variadas, em geral são secreções que servem para proteção das plantas ou mesmo como reserva de nutrientes. O látex geralmente é associado à borracha, material que é encontrado em milhares de espécies vegetais. Mas inúmeros outros produtos são extraidos do látex de diferentes espécies, entre os quais: goma de mascar, gutta percha (goma mais dura, antigamente utilizada para revestir cabos telefônicos oceânicos e para produtos odontológicos), ou produtos farmacêuticos, como a morfina. 
anos de 1884 e 1898, da produção de borracha da mangabeira, encontrada naturalmente em várias regiões entre São Paulo e Pernambuco ${ }^{10}$. Defendia-se que a mangabeira, abundante em forma nativa nos campos paulistas, era preferivel à seringueira por dela se extrair mais facilmente o látex. Alguns artigos de periódicos especializados (The India-Rubber and the Gutta-percha Journal e Boletim do Kew Gardens), constantes nesse arquivo, relatam os esforços para o cultivo da mangabeira nos últimos anos do século XIX, sob a influência da mesma queda internacional de preços já mencionada, que favoreceu que se considerasse a diversificação da produção. O intento de produzir borracha destas duas espécies era tamanho que, em 1899, uma lei estadual definiu uma série de prêmios em dinheiro para quem comprovasse ter viabilizado plantios ou a extração nativa. Reforçando o que falávamos sobre a importância das ferrovias naquele tempo, os valores de premiação eram mais altos para quem estivesse localizado a menos de 60 quilômetros de uma ferrovia.

Catramby (1913) apresentou uma monografia à exposição nacional da borracha no ano de 1913 sobre a indústria da borracha em São Paulo. Nesse evento, ocorrido sob o impacto da perda da liderança do mercado mundial da borracha em 1911, foram apresentadas monografias sobre o estado da arte da produção de borracha a partir de diversas plantas, em diferentes estados brasileiros. No caso de São Paulo, a atenção do autor estava voltada à mangabeira e à maniçoba, que eram as plantas laticiferas então recomendadas para o plantio, em uma época em que não se havia afirmado peremptoriamente nem mesmo no Oriente a proeminência da Hevea como espécie preferencial ao cultivo. Catramby chega a afirmar que a maniçoba do Ceará (Manihot glaziovii) seria recomendável para a plantação no estado de São Paulo. Um entrave, no entanto, teria inviabilizado a exploração comercial das árvores que atingiram o período de maturidade:
As plantações, aquellas que em pequeno numero actualmente escaparam ao machado destruidor, estão todas abandonadas, devido á dificuldade que encontraram os plantadores de um processo racional de extracção do latex. [...] Mas até agora não se descobriu ainda um meio de se fazer a extracção sem se produzirem numerosas incisões [...] A sangria feita com machadinha, processo das seringueiras, altera profundamente os tecidos e produz excrescencias que muito prejudicam as extracções seguintes [...] só as estações experimentais [...] poderão dar solução a essa parte. talvez a mais importante do problema da exploração comercial das maniçobeiras (CATRAMBY, 1913, p. 20-21; grifo nosso).

Esse trecho mostra que os métodos então utilizados na Amazônia para a extração do látex da Hevea, com a machadinha, foram tentados sem sucesso nas plantações experimentais de maniçoba de São Paulo, mas também comparados com os métodos que se desenvolviam no Oriente. Isto reforça este periodo da virada dos séculos XIX e XX como momento de profusão de formas de extrair látex das diversas espécies produtoras de borracha (DI DEUS, 2017). O não desenvolvimento de um método de extração adaptado às particularidades da maniçoba foi considerado pelos especialistas da época, segundo Catramby (1913, p. 21), como um dos principais problemas que impediram o avanço desta cultura, reforçando a importância das técnicas de extração para toda a indústria da borracha.

Outro pequeno trecho da monografia de Catramby nos mostra que a seringueira pode ter chegado a São Paulo, na esteira da primeira expansão cafeeira para o interior, na região de Ribeirão Preto, alguns anos antes das famosas sementes de Rondon, e contemporaneamente a esses esforços de se produzir borracha que priorizavam as outras espécies laticiferas. Tratar-se-iam de "sementes e pés" vindos do Ceilão, por obra de ingleses.

No Estado de S. Paulo, fomos informados, se fez nas fazendas Dumont um ensaio de plantação de seringueira, ensaio esse que teve o maior insuccesso, porque a plantação foi feita com sementes e pés vindos de Ceylão, mandados vir por um dos inglezes, di- 
rectores da companhia, chegando todas em más condições de cultura [...] O agente encarregado de visitar essas fazendas nos communicou que, em Ribeirão Preto, teve noticia desse ensaio feito nas fazendas Dumont, mas que "os administradores das fazendas, logo que o preço do café melhorou, cortaram os pés de seringueira e da madeira fizeram pequenos tocos para cercarem as covas dos pés de café" (CATRAMBY, 1913, p. 30).

É de se imaginar que estas árvores não deixaram descendentes, pois, a tomar por este relato, não parecem ter atingido a maturidade. Mas a informação dá a dimensão do grau de dispersão que as sementes e mudas de seringueiras tinham ao redor do mundo, e também como a seringueira manteve relação estreita com a cafeicultura no interior de São Paulo.

As seringueiras de Gavião Peixoto, nascidas das sementes enviadas por Rondon em 1915. cresceram vigorosamente na região central do estado, revelando a viabilidade destes plantios em uma região então considerada inapta por se localizar muito ao sul e em uma altitude relativamente elevada. Segundo Camargo, o mérito do pioneiro plantio do Coronel Ferraz foi comprovar que "a seringueira poderá ser cultivada no planalto paulista, à altitude de 550 metros, em latitude de $22^{\circ}$ sul do Equador" (CAMARGO, 1958, p. 21). No entanto, pouco se investiu para isso nas primeiras décadas do século XX. Em Gavião Peixoto os experimentos de sombreamento do café com a seringueira constataram a inadequação deste consórcio, que reduzia a produção de grãos.

Realizaram-se alguns experimentos na década de 1940, incluindo aquele implantado na fazenda experimental do Instituto Agronômico de Campinas (IAC), cuja comparação entre a produtividade das árvores plantadas de sementes de Gavião Peixoto e de sementes de alta produtividade vindas da estação de Deodoro, no Rio de Janeiro (essas provenientes das plantações da Firestone na Libéria, cruzamento de clones TJ), indicavam que o material selecionado geneticamente tinha produção muito maior (CAMARGO, 1958, 1960; CARDOSO, 1976). Mas seria somente a partir dos anos 1950 e 60 a seringueira ganharia força como um cultivo complementar, capaz de ocupar terras com cafezais antigos e diversificar sua economia.

Entre a introdução bem-sucedida propulsionada por Rondon em 1915 e os novos rumos a partir dos anos 1950, algumas transformações no panorama da Hevea no Brasil ocorreram. A principal experiência foi a de Fordlândia, uma cidade em moldes americanos erigida pela Ford Company às margens do rio Tapajós, no Pará, junto a uma gigantesca plantação de seringueiras, entre os anos 1920 e 1930. Embora tenha falhado no intuito de viabilizar uma plantação produtiva, devido ao ataque severo do mal-das-folhas, este empreendimento configurou uma intensificação das trocas de materiais genéticos e técnicas com os plantios de Ásia e África, na busca por variedades produtivas e resistentes à doença fúngica.

\section{O crescimento das plantações em São Paulo}

Enquanto isso, em São Paulo, a partir dos anos 1950, paralelamente aos trabalhos que ocorriam no plano nacional - principalmente na Amazônia e na Bahia - intensificaram-se as iniciativas para a promoção da heveicultura, sob o impacto das primeiras importações de borracha asiática, em 1951, e com o estímulo das indústrias de artefatos de borracha, ${ }^{11}$ mobilizado pelo então diretor do Instituto Agronômico de Campinas (IAC). ${ }^{12}$ Em um relatório ele descreve este momento:

[Entre 1951 e 1952] ainda mais se agravou a situação da indústria paulista de artefatos de borracha, pela falta crescente de matéria prima, que tem sido importada do estrangeiro, em quantidades cada vez maiores. Assim sendo, torna-se premente o estabelecimento de novas fontes nacionais de látex, além de se tentar aumentar a produção dos seringais nativos. Felicitações são devidas aos organizadores do "Consórcio Industrial de Incentivo à Borracha S.A.", recente-

11 Esse e os próximos parágrafos são baseados em CAMARGO, 1958, 1960; CORTEZ, 1986, GONÇALVES, $2002 ;$ MARTINEZ, 2006.

12 Um fato indica o protagonismo das indústrias de artefatos de borracha, sobretudo as pneumáticas, em toda a cadeia. Em 1952, como parte das medidas para reverter a recente perda na autossuficiência na produção de borracha natural, o governo federal edita uma lei que obrigava as empresas com fábricas no Brasil a investir 20\% de seus lucros anuais no plantio da seringueira. Goodyear e Pirelli plantaram no Pará, enquanto Firestone, Dunlop e Pneus Geral plantaram na Bahia (CATI, 1974, p. 3; DEAN, 1989, p. 170). 
mente fundado em São Paulo e que certamente contribuirá, eficazmente, para a instalação da cultura racional da seringueira no Brasil (KRUG, 1952, p. 1).

Em 1952 o IAC importou das Plantações da Firestone na Libéria, África, sementes híbridas de variedades de alta produção (híbridas dos clones Tjir $1 \times$ Tjir 16), que forneceram material para um esforço inicial, durante esta década, com a instalação de viveiros para produção de distribuição de mudas. Entre 1956 e 1961 o Serviço de Expansão da Seringueira, instalado por decreto do governador, e o Projeto ETA50 (um acordo entre a Secretaria Estadual de Agricultura, Ministério da Agricultura e o Escritório Técnico de Agricultura Brasil/Estados Unidos), somaram-se aos esforços de pesquisa que o Instituto Agronômico vinha realizando desde 1941. Foi neste periodo que uma grande diversidade de clones desenvolvidos na Ásia foi introduzida em São Paulo, a partir de iniciativa conjunta do Serviço de Expansão da Seringueira e do IAC, que passaram a constituir jardins clonais para a difusão da cultura por meio da técnica de enxertia (MARTINEZ, 2006, p. 2; CARDOSO, 1979, p. 39).

Não somente as indústrias de itens de borracha incentivavam a seringueira neste periodo, mas também o setor cafeeiro. Um exemplo deste apoio e articulação entre as culturas de café e seringueira foi a recomendação, em 1958, por parte do Instituto Brasileiro do Café (IBC), para que a Comissão Executiva da Assistência à Cafeicultura do Ministério da Agricultura arcasse com 50\% dos custos da compra de um lote de sementes de alta produtividade, "tendo em vista o plano da Secretaria da Agricultura de São Paulo, de pretender introduzir a cultura da seringueira para substituir, parcialmente, as lavouras decadentes de café do Estado" (CAMARGO, 1958, p. 55).

Foram instalados viveiros em "campos de cooperação" (CORTEZ, 1986, p. 3) em parcerias destas instituições estaduais com fazendeiros, para alavancar a produção de mudas e disseminação da seringueira. Segundo Cardoso, o Serviço de Expansão da Seringueira, quando este programa foi oficialmente encerrado em 1959. "chegou a distribuir mais ou menos, 600.000 mudas enxertadas" (1979, p. 36). Não obstante a existência de seringueiras plantadas no planalto que cresciam bem na fazenda do IAC em Campinas e em algumas fazendas pioneiras, como na própria plantação do Coronel Ferraz com sementes de Rondon, a prioridade inicial destas políticas foi o litoral paulista, então definido como área mais indicada para esta cultura, segundo critérios técnico-científicos da época, baseados em fatores climáticos:

Considerando que esta planta é exigente quanto ao clima, necessitando para o seu rápido desenvolvimento de uma queda pluviométrica elevada e bem distribuida pelos 12 meses do ano, e, ainda. temperaturas relativamente elevadas a zona mais indicada no Estado de São Paulo é, sem dúvida, o seu litoral. [...] Não resta, porém, a menor dúvida de que dentro do Estado, o litoral deve ser considerado em primeiro lugar para a implantação desta cultura entre nós (KRUG, 1951, p. 2, grifo nosso).

Esse quadro mudaria a partir de 1961, quando o famigerado mal-das-folhas acometeria as plantações do litoral e diminuiria o entusiasmo com a nova cultura. Paralelamente, estudos de climatologia indicavam que, mesmo com indices pluviométricos menores do que a média da Amazônia ou do litoral paulista, um olhar mais acurado para o balanço hídrico entre precipitação e a perda de água pelas plantas indicava o planalto paulista em condições ideais para o cultivo da seringueira, até melhores do que, por exemplo, a região de Fordlândia, no Pará, que apresentaria déficit hídrico (PAES DE CAMARGO, 1958, p. 9). Isso com a vantagem de no planalto existir uma bem marcada estação seca, na qual há uma regular perda das folhas, que constitui uma proteção contra o mal-das-folhas, sendo posteriormente considerada "área de escape climático"13. É depois da eclosão do Microcyclus no litoral que ganha força a ideia de incentivar esta cultura que já vinha crescendo bem no planalto:

13 Áreas menos propícias ao desenvolvimento dos fungos causadores do mal-das-folhas. 
Ao mesmo tempo em que se procedia aos plantios de seringais no litoral paulista, área inicialmente escolhida por apresentar parâmetros ecológicos próximos aos observados nas regiões de origem da seringueira, era tentada a implantação desta cultura no planalto paulista. A existência de exemplares com ótimo desenvolvimento em algumas zonas do planalto, ensejava um futuro promissor para a heveicultura. Do mútuo trabalho do Serviço de Expansão da Seringueira e do Instituto Agronômico, quer na troca de material clonal, quer na discussão de problemas inerentes à implantação da nova cultura, surgiram os primeiros seringais racionais em terras do planalto paulista. Desses seringais pioneiros é que se obtiveram os resultados práticos de que hoje lançam mão aqueles que lidam com a seringueira para apregoar a reivindicar uma heveicultura para São Paulo (CARDOSO, 1979, p. 45).

Não obstante o mito fundador da seringueira com Rondon e Ferraz, ou mesmo as experiências anteriores com outras espécies laticiferas, a heveicultura em São Paulo se viabiliza, portanto, após este esforço de transferência de tecnologia a partir dos anos 1950, baseada nos sistemas técnicos desenvolvidos nas plantações orientais que passaram a circular nestas redes internacionais pelo mundo tropical. Mesmo a importação pioneira em 1952 de material da Firestone tendo sido de sementes hibridas de clones produtivos, a heveicultura paulista se estruturou a partir da importação de borbulhas para produção de mudas enxertadas a partir de clones asiáticos de alta produtividade. Seguiramse algumas importações por parte dos órgãos estaduais, sempre com suporte da rede de produtores, e até mesmo de instituições ligadas aos produtores de café ${ }^{14}$

Foi o início de um programa de pesquisas existente até hoje no Instituto Agronômico de Campinas (IAC), com o foco no desenvolvimento de clones de alta produtividade adaptados ao estado de São Paulo, testado em diversas estações de pesquisa espalhadas pelo estado, onde todo este material importado, somado a coletas realizadas na Amazônia, são há algumas décadas experimentados. Para se ter uma ideia da temporalidade própria destas pesquisas, há clones das séries 300 e 500 do IAC considerados produtivos e promissores, selecionados nestas décadas de pesquisa, mas que não atingiram ainda a chamada Classe 1 de recomendação, para plantio em larga escala. Nesta classe se encontram apenas três clones de origem asiática, incluindo o hegemônico RRIM 600 (IAC, 2017) ${ }^{15}$.

A partir dos anos $1960 / 70$ já se confirmava o que as plantações pioneiras haviam indicado: as seringueiras cresciam vigorosas e sadias no planalto ocidental. Em tese, portanto, estavam garantidas as bases para as plantações florescerem na região. As apostas das pesquisas se concentraram no melhoramento genético da seringueira, na busca pela "criação de variedades adaptáveis às condições do meio paulista" (CAMARGO, 1958, p. 24).

\section{O que fazer do seringal, pic-nic ou lenha?}

No entanto, restava ainda a questão central: como viabilizar a extração da borracha? Foi só a partir daí que um elo fundamental de toda esta cadeia ganhou atenção: o sangrador (ou seringueiro).

Em meados dos anos 60, quando os seringais instalados com mudas distribuidas para plantio em 1959 começavam a apresentar um número razoável de árvores em condições de serem sangradas para a extração do seu látex, demos início a um programa de treinamento das primeiras equipes de sangradores. Agora, sem podermos mais contar com a estrutura e os recursos disponiveis durante a vigência do Serviço de Expansão, era chegada a hora da verdade, da cobrança: "Se a Secretaria da Agricultura mandou nós plantarmos seringueira, gostariamos de saber se é viável a sua exploração comercial ou se devemos transformá-la em um bosque para fazer 'pic-nic' ou lenha?", perguntavam os agricultores (MARTINEZ, 2006, p. 2, grifo nosso)

Subjacente a essa ideia de viabilidade está a possibilidade de efetivamente das árvores retirar

\footnotetext{
14 Parágrafo baseado em: CAMARGO, 1958; HOELZ; MARTINEZ, 1972; CARDOSO, 1979; CORTEZ, 1986.

15 Curioso é que, ainda em 1958, Camargo relatava ter visto um processo semelhante na Malásia, onde havia "preocupação exagerada" em não recomendar e aceitar novos clones (CAMARGO, 1958, p. 12).
} 
a borracha. Para isso, era fundamental treinar os trabalhadores que seriam responsáveis pelas "técnicas de sangria da seringueira, uma prática altamente especializada e delicada para o sucesso econômico da sua exploração" (MARTINEZ, 2006, p. 2). Martinez menciona, assim, o que passou a ser o grande desafio nos anos 1960 e 1970, quando já se sabia que cresciam bem no planalto as variedades produtivas asiáticas, mesmo não sendo resistentes ao mal-das-folhas, doença que à época atacava plantações amazônicas e litorâneas na Bahia e no vale do Ribeira ${ }^{16}$.

Hoelz e Martinez (1972, p. 60-64) falam na existência de dois períodos principais até os anos 1970: o periodo "fomentista" e o da "expectativa". O primeiro foi o período, nos anos 1950, em que o Serviço de Expansão da Seringueira incentivou a difusão da cultura, com investimentos em aquisição de material botânico e primeiro impulso na plantação de seringueira, com distribuição de mudas por todo o estado ${ }^{17}$. Este ânimo fora arrefecido, em termos de políticas públicas, com o aparecimento do Microciclus no litoral, em 1961. Falou-se em um período de "recesso total" (CORTEZ, 1986, p. 2) após este baque, que duraria até 1966/67. É justamente nesse momento, na virada dos anos 1960 para 1970, que cresce a "expectativa" quanto à possibilidade de fazer essas árvores produzirem borracha. 0 principal desafio passa a ser não mais a questão da genética, da sanidade do plantio, mas sim a viabilização da sangria, da extração da borracha.

Os novos projetos de apoio à cultura da seringueira que se seguiram nessa fase de "expectativa", passaram a contemplar ações de assistência técnica na chamada "exploração" do seringal. Primeiramente a CATI, órgão de assistência técnica do governo paulista, fomentou a criação de dez "Centros-Piloto de Sangria e Preparo do Látex" em propriedades privadas espalhadas por todo o estado. Os dois primeiros, instalados em 1967, localizaram-se nos municípios de Bálsamo (próximo a Rio Preto) e Colina (próximo a Barretos). Dos dez primeiros, 7 se instalaram no planalto, contra 3 no litoral, o que já indicava uma inversão de prioridades (CATI, 1974, p. 29). O desafio era transferir tecnologia na esfera da "exploração" dos já crescidos e vigorosos seringais, ou seja, como extrair o látex das árvores e processar esta borracha.

Mesmo com a instalação dos centros-piloto a partir de 1967, muitos seringais plantados no periodo "fomentista" continuaram "virgens" até meados da década de 1970, alguns com idades de 13 a 15 anos (sendo que a partir de 7 ou 8 anos já se pode, em média, iniciar a sangria). Para reverter essa situação a CATI elaborou um projeto de assistência técnica visando formar sangradores, técnicos e agrônomos, cujos objetivos gerais eram: "Colocar em regime de produção os seringais maduros existentes e ainda virgens, por falta de programa de assistência técnica. Estabelecer áreas de demonstração para através das mesmas promover a expansão da cultura do Estado" (CATI, 1975, p. 7). O projeto previa capacitações em vários niveis: uma viagem de estudos de um agrônomo às regiões produtoras da Ásia e África; capacitar agrônomos e auxiliares em técnicas de sangria e, por fim, capacitar "operários" (os sangradores) na técnica de sangria.

Esse projeto previa ainda a aquisição de uma máquina centrífuga para processamento do látex, instalada em um dos primeiros centros-piloto, em Colina. Isso é mais um exemplo de que, mesmo havendo um significativo investimento de capital próprio dos patrões que convertiam parcelas de seus cafezais e outras culturas para seringais, houve expressivo e determinante investimento público na história do estado que se tornou lider da heveicultura no país. A opção pela aquisição desta máquina de processamento do látex sinaliza a importância que esta forma de comercializar a borracha, preservada liquida, teve nesse periodo.

Se havia uma preocupação muito grande 
com o fornecimento de borracha para as indústrias paulistas, desde os anos 1950, esta preocupação era ainda mais intensa para aqueles ramos que demandam o látex em sua forma líquida. Preservar o látex líquido é uma forma de trabalhar a borracha mais sensivel ao transporte em longas distâncias. Assim, a indústria de luvas cirúrgicas e balões Xetal (que significava látex ao contrário), localizada em São Roque, que entrou no mercado no final dos anos 1960, não conseguia importar nem da Ásia nem da Bahia ou Amazônia o látex em boa qualidade. Seus caminhões rodavam o estado comprando de cerca de 90\% dos produtores paulistas o látex, pagando valores altos diretamente com cheques, estimulando os plantadores a iniciarem a extração (MARTINEZ, 2006, p. 3; CATI, 1974, p. 38). De modo distinto da situação atual, em que a grande maioria das fazendas vende o látex já coagulado nas próprias canecas coletoras, principalmente para as fábricas de pneus, naquele momento inicial, a demanda pelo látex líquido acabou sendo, portanto, um importante impulso para as incipientes plantações.

O estado apoiava a transferência de tecnologia para a exploração de seringais que cresciam vigorosos há alguns anos no planalto, enquanto a indústria paulista garantia a demanda pelo produto. A década de 1980 seria, nesse cenário, contando ainda com uma alta nos preços, um momento de crescimento exponencial da cultura da seringueira. Em 1981, com os bons resultados dos seringais que passaram a ser explorados, foi criado um programa estadual de borracha natural, o Pró-Borracha, visando ampliar a área plantada até 1990 para 50 mil hectares, contemplando financiamento adequado à heveicultura (juros baixos e carência de 7 anos), priorizando pequenas e médias propriedades, de 5 a 200 hectares, cujos projetos de plantio não poderiam ultrapassar metade da área (BACCHIEGA, 1981, p. 77; CORTEZ, 1986, p. 3). Dados da Secretaria da Agricultura de São Paulo, que elaborou poucos anos depois o Programa Estadual da Seringueira, indicavam uma verdadeira explosão da área plantada entre 1981 e 1986. De 2,2 mil hectares (em 183 propriedades em 84 municipios) no ano de 1980, passou-se a 8 mil hectares (705 propriedades, 156 municipios) em 1983. Em 1985 a área já estava em 15 mil ha (em 893 propriedades de 196 municipios), com estimativa para 1986: 18 mil hectares em mais de 1000 propriedades de 200 municipios. Em resumo, um crescimento de quase $800 \% \mathrm{em}$ cinco anos (SAA-SP, 1986, p. 16, 38).

Os plantios de seringueira cresciam, como já mencionado anteriormente, ocupando áreas de antigas e decadentes lavouras de café. Sendo uma das "melhores e mais seguras opções para o produtor rural diversificar sua atividade agrícola" (SAA-SP, 1986, p. 22), a heveicultura era propagandeada como tendo muitos "benefícios":

Os benefícios decorrentes dessa expansão não se limitam, entretanto, ao volume de borracha produzido. Além da alta rentabilidade conferida ao produtor, a atividade gumifera, cuja extração depende de mão-de-obra semi-especializada, irá contribuir para redução da migração rural e na melhoria das condições de trabalho do operário rural, principalmente devido à não sazonalidade do trabalho de exploração. Passivel de ser introduzida em pequenas propriedades, a seringueira está sendo socialmente desejada como instrumento eficaz na manutenção da atual estrutura fundiária do Estado [...] O caráter de cultivo permanente, associado a alta lucratividade por unidade de área, além de permitir o cultivo intercalar de culturas anuais durante a fase de formação, conferem à cultura da seringueira características de instrumento útil à estabilidade econômica financeira do pequeno produtor rural (SAA-SP, 1986, p. 5-10).

O engenheiro agrônomo Antônio Bacchiega, da Secretaria da Agricultura na regional de Rio Preto, conclui seu compêndio de "noções" para o cultivo da seringueira apresentando um quadro comparativo do rendimento monetário por hectare da seringueira: essa era mais de 3 vezes mais lucrativa do que laranja e café (BACCHIEGA, 1981, p. 81).

Mas havia alguns "pontos de estrangulamento", dentre os quais o principal era a "falta de preparo de mão-de-obra especializada em técnicas de sangria" (SAA-SP, 1986, p. 40). Tendo em vista que "A sangria de seringueira realizada de maneira correta 
é condição essencial para garantir a qualidade do produto extraído e aumentar a vida útil dos seringais" (SAA-SP, 1986, p. 31), foram incluídas novas atividades de capacitação e "atualização de técnicos". Assim, uma década depois das primeiras ações de assistência técnica sistemática em sangria, uma das propostas centrais do Programa Estadual de Seringueira em 1986, continuava sendo o treinamento de sangradores e agrônomos que formariam novos sangradores.

Desde 1976 a CATI já contava com apoio federal ao manter convênio com a então existente Empresa Brasileira de Assistência Técnica e Extensão Rural - EMBRATER, no esforço de transferência inicial de tecnologias de exploração dos seringais (SAA-SP, 1986, p. 4). Mas, somente após uma década de existência do Programa de Incentivo à Produção de Borracha Vegetal (PROBOR), a partir dos anos 1980, é que o estado conseguiu se integrar a este esforço que o governo federal, por meio da Superintendência da Borracha (SUDHEVEA), fazia para alavancar a produção da borracha. Foi só em 1985 que a SUDHEVEA se incorpora ao Programa da Seringueira em São Paulo, com a instalação de um escritório regional em Campinas e um escritório local em Rio Preto (CORTEZ, 1986, p. 3). O já mencionado Programa Estadual de 1986 continha ações integradas ao PROBOR, sobretudo visitas técnicas aos projetos de novas plantações financiados pelos recursos federais (SAA-SP, 1986, p. 22-26).

São Paulo passou assim, na década de 1980 , para o hall dos grandes produtores de borracha atendidos pelas políticas públicas federais. Em poucos anos, no início da década de 1990 , ultrapassaria o Mato Grosso e a Bahia como maior produtor de borracha natural em plantações, e assumiria a posição que mantém até hoje de liderança na produção nacional de borracha. Foi o que prenunciou, em tom de orgulho regionalista, um importante engenheiro agrônomo da secretaria da agricultura de São Paulo ao se referir ao sentimento dos representantes de São Paulo no I Seminário Nacional da Seringueira, realizado pela Sudhevea em Cuiabá-MT no ano de 1972:

\begin{abstract}
Ali, para surpresa nossa, pela primeira vez, podiamos discutir o assunto seringueira com os colegas representantes dos estados tradicionais produtores de borracha do Acre e da Amazônia [SIC], do Mato Grosso e da Bahia, sem medo, sem preconceito. Foi nesse ambiente que, embora nos sentíssemos meio deslocados, como um convidado 'penetra', pudemos ter uma visão mais realista das precariedades da nossa agroindústria extrativa da borracha e ver reforçada a nossa convicção de que, graças ao potencial agrícola do nosso estado e da capacidade empresarial do nosso agricultor, São Paulo, um dia, daria a sua resposta (MARTINEZ, 2006, p. 3).
\end{abstract}

\section{Considerações finais}

São Paulo foi o estado mais bem-sucedido na "transferência de tecnologia" heveicola que se intentou intensamente, por sucessivas políticas públicas federais, da Ásia e África desde a década de 1950, quando o Brasil passou a importar a borracha, até a de 1980, quando a Superintendência da Borracha foi extinta e incorporada ao recém criado Instituto Brasileiro do Meio Ambiente e dos Recursos Naturais Renováveis - IBAMA

A emergência de novos cultivos em substituição ou em consórcio com cultivos anteriores tem sido tratadas nos estudos rurais no Brasil sob o termo "reconversões", termo que aponta para diferentes tipos de mudança. Afrânio Garcia Jr. (1988) usou o termo "reconversão econômica" para compreender as estratégias dos proprietários de fazendas de cana de açúcar de diversificar suas atividades econômicas (outros cultivos ou mesmo em outras atividades como comércio) no Nordeste para se manterem como senhores de engenho. O termo parece ter se popularizado nos estudos rurais, para tratar de processos distintos de mudanças que envolvem trabalhadores rurais e sociedades camponesas, incluindo ideias como "reconversão de condições sociais" (GARCIA JR.; HEREDIA, 2009, p. 239) e até "reconversão identitária" (GOMES, 2009, p. 324).

Neste artigo estamos chamando a atenção para transformações nos sistemas técnicos como processos que podem ser considerados a partir das relações que as pessoas estabelecem com 
os seres vivos e os objetos técnicos. Foi esse o motivo de um olhar para a diáspora da seringueira pelo mundo: esta árvore viajou, não apenas como material botânico isolado em sementes e mudas, mas como um conjunto de relações e sistemas técnicos que no Oriente se reconfiguraram no modo de plantação, não sem se beneficiar de conhecimentos e técnicas previamente construidos na Amazônia por indigenas, seringueiros e pesquisadores (DI DEUS, 2017).

Seu retorno para o Brasil no modo de existência em plantações com seus peculiares sistemas técnicos, especialmente na articulação com o café paulista, nos mostra que a compreensão da relação das pessoas com plantas cultivadas pode ser beneficiada se articularmos o olhar dos estudos rurais para as "reconversões econômicas" com uma abordagem de transferência de tecnologia baseada na perspectiva daqueles que se apropriam dos objetos e processos técnicos, daqueles que manejam e interagem com os seres vivos. Aqui fazemos referência tanto à perspectiva das "escolhas técnicas" (LEMONNIER, 1993) quanto à perspectiva de apropriação de objetos técnicos, discutida por Akrich (1992), ambas indicando que a transferência de tecnologia é um processo que envolve principalmente os complexos mecanismos de recepção por parte dos utilizadores. Neste entendimento, os utilizadores não têm apenas "cultura" (enquanto os desenvolvedores seriam os detentores exclusivos "da" técnica), mas têm uma tradição técnica, e também um protagonismo técnico.

A grande maioria dos seringais da região são na atualidade vizinhos de plantações de cana de açúcar e de pastagens ${ }^{18}$. Segundo - Levantamento Censitário das Unidades de Produção Agropecuária do Estado de São Paulo (LUPA 2007/08), no Escritório de Desenvolvimento Regional (EDR) de São José do Rio Preto a seringueira ocupava o quarto lugar em área plantada (com 21,5 mil ha), atrás de braquiária (264.9 mil ha), cana de açúcar (239.5 mil ha) e laranja (39.5 mil ha). Se considerarmos, porém, o número de propriedades rurais (chamadas de Unidades Produtivas Agropecuárias - UPAs) que continham cada cultivo, a seringueira passava a laranja e assumia o terceiro lugar, pois tinha plantações com média de 17 ha/UPA, bem menor do que a média dos plantios em cada propriedade com laranja (38 ha/UPA). Outro dado relevante: a maior área plantada de seringueira em uma UPA da região tem 603 hectares, enquanto a maior de laranja tem 3.3 mil ha e a maior de cana de açúcar tem 4,3 mil ha. Ou seja, a seringueira, em comparação com a laranja, a cana e as pastagens, tem o tamanho das plantações em cada propriedade relativamente bem menor.

Quase sempre os seringais dividem espaço dentro das mesmas propriedades com esses outros cultivos, principalmente pastagens e cana.19 É muito comum que as numerosas usinas de álcool e açúcar da região arrendem áreas para o plantio de cana. Mas nem sempre foi assim. A maioria dos seringais foi surgindo aos poucos, com pequenos plantios. Os pioneiros surgiram entre as décadas de 1950 e 1970, processo que se intensificou a partir dos anos 1980 e 1990. Aárvore amazônica foi substituindo ano a ano pequenas parcelas dos antigos cafezais e laranjais, que então configuravam os principais cultivos agricolas na região, ao lado da pecuária. Foi assim em uma fazenda onde realizei pesquisa etnográfica, com um sangrador que ali trabalha em parceria com o patrão há mais de vinte anos. A história das reconversões de cultivos nessa fazenda, relatada por ele, é exemplar do que se passou na região.

Quando Jair chegou a esta fazenda, no início dos anos 1990, os talhões de seringueira mais antigos já estavam ali, com mais de dez anos

18 Os Escritórios de Desenvolvimento Regional (EDRs), são recortes menores do que as chamadas Mesorregiões. A Mesorregião de Rio Preto abrange uma parte do que se chama de noroeste paulista. Infelizmente não foi possivel analisar os dados do novo LUPA (2017/18), em fase de elaboração pelo governo estadual. No entanto, os dados do IBGE apontam para um significativo crescimento da área plantada com seringueiras nos últimos anos, passando de 41 mil ha em 2007 para 60,4 mil ha em 2015. um aumento de quase 50\% na mesorregião de Rio Preto. É preciso informar que há uma diferença significativa entre os dados do IBGE e do governo estadual, havendo números muito inferiores no primeiro.

19 Francisco et al. (2009, p. 25) informam que, segundos dados do LUPA 2007/08, em 68\% das propriedades nas quais há seringueiras também se encontravam pastagens com braquiária, sendo que em mais de 50\% há algum tipo de bovinocultura, além de que em 32\% havia também cana de açúcar e em $12 \%$ laranja. 
de idade, e tinham sido plantados no vão do cafezal. Plantar no vão é uma maneira de fazer a conversão de um cultivo perene a outro sem eliminar o antigo imediatamente ${ }^{20}$. Planta-se a muda de seringueira na mesma linha do café. Quando a árvore da borracha ultrapassa a concorrente, esta última é cortada. Eram recentes também os talhões que atualmente são os mais produtivos, plantados "no vão" da laranja. Dessa forma, a história dos cultivos está inscrita na paisagem, no espaçamento dos atuais seringais. Jair viu muitos outros "talhões" serem plantados, substituindo áreas de café, de laranja, de manga, de grãos e de pastagem para o gado leiteiro ${ }^{21}$. Desta maneira, em uma única fazenda vemos resumida a história da relação da seringueira com outros cultivos que já foram majoritários na região. Primeiramente o café, que resistia ainda nos anos 1970 e 1980. Em seguida, a laranja, nos anos 1980 e 1990. Por fim, a cana de açúcar, nos últimos anos. Ao longo de todo o tempo também houve a coexistência com a pecuária bovina. Estes ciclos não foram rígidos, no entanto.

Quando visitei a fazenda onde Jair trabalha, na primeira incursão exploratória para o trabalho de campo, em agosto de 2012, o último talhão de laranja estava com os pés carregados de frutas que não seriam colhidas. O baixo preço dessa fruta determinaria o fim da citricultura na fazenda, com mais um talhão substituido por seringueira. Em uma fazenda vizinha, no entanto, vi ainda em 2015 um talhão de laranja com a seringueira "no vão", prestes a ultrapassar a altura dos pés de laranja. Por outro lado, há uma sucessão de momentos de apogeu de cada cultivo. Os talhões mais antigos, já próximos do fim da vida produtiva, com árvores de mais de trinta anos, substituíram em geral plantios de café. Alguns talhões em plena maturidade foram plantados no vão da laranja, nos anos 1990. Atualmente a paisagem mais comum nos seringais da região são as moitas ${ }^{22}$ de seringueira circundados por extensas áreas de cana de açúcar.

As reconversões que fizeram emergir a seringueira em São Paulo, portanto, tiveram características muito peculiares. Diferente de modelos comuns na Ásia e África, seja da grande plantação ou do pequeno produtor proprietário de plantações muito pequenas (smallholder). Diferente também do modelo implantado por corporações pneumáticas que se instalaram no Brasil, como a Firestone na Bahia e a Michelin na Bahia e Mato Grosso, reproduzindo o modelo da grande plantação que estas empresas já empregavam em outros continentes, com assalariamento e estrutura hierárquica de fiscalização do trabalho. Os sangradores que migraram do Mato Grosso para São Paulo, que já trabalharam para a Michelin, usam a expressão "sistema sufocante" ou "abafante" para descrever o trabalho e a vida naquele contexto. Em São Paulo a seringueira emergiu da reconversão produtiva progressiva dos monocultivos principais, café e laranja, em um contexto de unidades produtivas relativamente bem capitalizadas, como cultivo secundário. Nessas configurações, diante da exigência de habilidade técnica para a sangria de seringueiras, operação crucial do seringal e que é executada durante quase o ano todo, a seringueira emergiu em pequenos e médios cultivos no planalto paulista (média de 17 hectares) com os sangradores sendo contratados como parceiros agrícolas, quase sempre residindo na propriedade. Nesse contexto, de um cultivo

\footnotetext{
20 Stolcke (1986, p. 193-194) revela que algo similar já era feito nos anos 1950 em processos de renovação dos próprios cafezais. Chamada de "dobração", esta prática se baseava no mesmo principio de plantar, nas mesmas ruas dos pés velhos, novos pés de cafés, recurso que possibilitava a continuidade da exploração das árvores antigas até que as novas atingissem idade produtiva. A dobração, no entanto, segundo a autora, foi um empecilho para que a renovação dos plantios se desse com inovações técnicas disponiveis, segundo as recomendações do governo estadual: "essa prática impedia a introdução do plantio em curva de nível e do menor espaçamento e, de fato, perpetuava o antigo traçado da plantação" (Ibid., p. 194).

21 Mas, como é o mais comum na região, nunca participou diretamente do plantio e manutenção das árvores nos seus primeiros sete anos, em média, tempo necessário para que estejam aptas a serem sangradas. Como a grande maioria dos sangradores da região, é um sangrador especializado nas atividades de extração, embora dedique algum tempo a pequenas criações (porcos, peixes, galinhas), roçados e hortas. Mas nem todos os sangradores atuais fazem isso, alguns dedicam a totalidade de seu tempo na fazenda às tarefas de extração. Jair é parceiro, nunca pensou em trabalhar como assalariado. Junto da esposa e de filhos trabalhou sempre em equipes, hoje reforçadas por ajudantes e diaristas.

22 Moita é como localmente são chamados alguns talhões de seringueiras não muito grandes.
} 
que começou aos poucos e não como um cultivo principal, a parceria parece ter sido o modo de relação ideal justamente por prescindir de investimentos maiores na fiscalização do trabalho.

Ao contrário da terra arrasada promovida pela cana de açúcar, a seringueira manteve e transformou certas estruturas do café. O professor Osmar Figueira, agrônomo que ministrou o curso de sangria do qual fui aluno, disse-me que uma expressão comum para a substituição progressiva de partes dos antigos cafezais, com o plantio de seringueiras no vão, era: "a borracha que apaga o café". Osmar disse também, tendo a cana de açúcar como pano de fundo, que "a seringueira lembra muito o café; o que a cana expulsou, ela resgata"23. Osmar faz referência a certas relações mais duráveis do trabalhador com a terra, que estas culturas baseadas no plantio de árvores de médio e longo prazo proporcionam, em oposição à voracidade dos ciclos curtos da cana, que transformou a paisagem do interior paulista. De certa maneira, a seringueira "resgata" certas relações presentes no café, mas também as transforma.

As pequenas vilas de moradores nas franjas das plantações, algumas das quais com os antigos terreiros de secagem do café, permanecem, para abrigar as familias de sangradores, que precisam estar próximos das árvores que sangram. Por outro lado, ao contrário da própria cafeicultura, na qual o colonato 24 desapareceu nos anos 1960 e deu lugar ao trabalho assalariado eventual (o "boia fria"), a seringueira emergiu, como vimos, gradativamente a partir desta época, mas recuperando uma forma de remuneração baseada na partilha da produção, a parceria agrícola. A necessidade de fiscalização do trabalho especializado do sangrador nas pequenas "moitas" de seringueiras que surgiam gradativamente em meio aos cafezais parece ter sido reduzida com a adoção da parceria agricola e do engajamento que esta forma de relação proporciona.
Muitas questões que vimos nessa abordagem histórica da emergência da heveicultura em São Paulo continuam pertinentes nos debates contemporâneos. A seringueira continua sendo o produto mais rentável da região, embora os produtores estejam sempre preocupados com suas margens de lucro (BACCHIEGA, 1981, p. 8;). A ideia de que muitos produtores preferem "roubar" os sangradores de outros, em vez de formá-los, continua presente, dentro da visão de que faltam trabalhadores qualificados para a sangria. O ponto principal diz respeito ao lugar do sangrador na heveicultura que, embora seja um elo fundamental desta cadeia é referido de hábito como o "problema da mão de obra".

Como vimos, a falta de um método eficaz para a extração da borracha da mangabeira e da maniçoba foi determinante para o insucesso dessa primeira agroindústria da borracha em São Paulo, no início do século XX (CATRAMBY, 1913). Ainda em sua experiência amazônica, quando propagandeava as plantações de seringueiras como importante mecanismo de desenvolvimento da região, o paulista Felisberto Camargo já destacava em um manual de heveicultura que "a sangria ou corte é outra operação das mais importantes, no cultivo da Hevea, tornando de todo necessário o conhecimento de uma série de medidas racionais, relacionadas com a sua prática, que devem ser tomadas em caráter quase obrigatório" (1952, p. 8-9), passando ao exame de uma série de parâmetros do que preconizava como boa sangria, tais como altura, profundidade, inclinação, direção, tipo, bem como os utensílios necessário à boa sangria.

Ainda no periodo "fomentista", ao ensinar as técnicas de sangria em seus cursos de formação de técnicos e agrônomos na cultura da seringueira, o chefe da Secção de Seringueiras e Plantas Tropicais ${ }^{25}$, Jacob Hoelz, enfatizava a grande "influência do sangrador" para os resultados da heveicultura (HOELZ, 1958, p. 133; HOELZ et al., 1961, p. 39).

${ }_{23}$ Beatriz Melo realizou tese recentemente sobre a resistência de pequenos sitiantes ao avanço da cana de açúcar no extremo noroeste paulista, na região de Jales, próxima da fronteira com o Mato Grosso do Sul, há cerca de 130 quilômetros de São José do Rio Preto. Neste contexto, Melo situa a seringueira ao lado de culturas frutiferas como possível vetor de resistência ao avanço da cana fazendo "uma cerca para que a cana não entre", nos termos de um sitiante que entrevistou (MELO, 2013, p. 218).

24 O colonato foi um sistema de trabalho complexo, que incluía um pagamento fixo por carpas em torno dos cafezais e o pagamento por produtividade das operações de colheita (Cf. MARTINS, 2010; STOLCKE, 1986).

25 Este órgão era vinculado à antiga Divisão de Assistência Técnica Especializada - DATE da Secretaria de Estado dos Negócios da Agricultura de São Paulo. A DATE foi posteriormente transformada em Coordenadoria de Assistência Técnica Integral - CATI. 
Mas foi sobretudo na chamada fase de "expectativa", como já ressaltado, em que o imperativo de viabilizar a produção de um conjunto de vigorosos seringais e já em idade de sangria, que a importância da sangria e do sangrador se tornou um tema incontornável. Mesmo com as árvores crescidas, o processo de extração não estava dado. Era preciso construir, "estabilizar" (LATOUR, 2000) esse outro conjunto de relações que pudessem viabilizar a extração. Ou seja, alinhar ou conectar diversos actantes heterogêneos, nos termos de Latour. Angelo Martinez, agrônomo do IAC, publica no suplemento agrícola dominical do jornal O Estado de São Paulo um artigo especialmente dedicado a difundir os parâmetros gerais da sangria. Entre explicações sobre a morfologia da casca (incluindo diagrama), a fisiologia do látex e detalhes dos procedimentos de uma sangria correta segundo os parâmetros da época, o autor inicia e finaliza o artigo com estas sintomáticas considerações:

O êxito da exploração econômica de uma cultura de seringueira depende muito do sangrador. O conhecimento da melhor técnica de sangria é, pois, necessário quando se deseja obter maior rendimento do látex, sem prejudicar a árvore e as sangrias [...] A influência do sangrador sobre a produção é maior do que geralmente se pode supor. Frequentemente o maior erro está em se tentar terminar rapidamente a tarefa. Como consequência, cortes violentos e irregulares produzem sangrias rasas ou profundas, com excessivo consumo de casca, o que facilita o aparecimento de lesões que irão prejudicar as sangrias e até mesmo a sanidade da árvore (MARTINEZ, 1971, p. 12; grifo nosso).

Seria possivel multiplicar a inserção de citações muito semelhantes acerca da importância do sangrador, que se estendem até análises socioeconômicas contemporâneas da cultura da seringueira em São Paulo, como a que se segue:

A atividade heveícola possui grande valor social, conhecida pela capacidade em geração de trabalho permanente, principalmente familiar, e também pelo caráter intensivo no emprego de mão-de-obra, dado que sua exploração não é mecanizada. [...] A sangria constitui-se na operação mais importante realizada num seringal, uma vez que está diretamente ligada à produção final. A figura do sangrador é de extrema relevância para a coleta do látex, já que se ele não for suficientemente treinado poderá acarretar não só enormes prejuizos financeiros, mas danificar totalmente o seringal. Nas mãos do sangrador está o resultado do investimento de muitos anos (FRANCISCO et al., 2009, p. 27; grifo nosso).

Se a viabilidade dos seringais foi posta à prova historicamente a partir da necessidade de sangrálos de modo eficaz, de formar sangradores, tratase de um reconhecimento de que o universo da sangria, que é o que conecta o humano ao vegetal, é o que torna possivel toda a cadeia. Para os agrônomos e outros agentes da heveicultura parece haver um problema da mão de obra, na medida em que se tem uma ideia especifica da produção. No entanto, em uma dimensão positiva do fenômeno, a perspectiva dos sangradores, destaca-se a complexidade antropológica envolvida no processo de extração, na medida em que estes trabalhadores fazem emergir um cultivo através de suas habilidades e engajamentos. Com isso, pretende-se evitar uma visão estritamente econômica, para ressaltar uma visão da técnica, centrada nos processos e operações. Na verdade, os agrônomos sabem bem que a cultura da seringueira não existiria sem a extração, mas eles sabiam, pelos experimentos e outros plantios existentes no mundo tropical, que a instituição da sangria era uma virtualidade - afinal, só é um "problema" aquilo com potencial para ser resolvido. Portanto, se os agrônomos veem aquilo como um elo na cadeia, os sangradores vivem essas experiências como a ontogênese de um modo de relação fundamental, com as árvores.

\section{Referências}

AKRICH, Madeleine. The de-scription of technical objects. In: BIJKER, Wiebe E.; LAW, John. (org.). Shaping technology - building society: studies in sociotechnical change. Cambridge; London: MIT Press, 1992.

ALMEIDA, Mauro William Barbosa de. Rubber tappers of the Upper Jurua River, Brazil. Tese (Doutorado em Antropologia) -- University of Cambridge, Cambridge, 1992.

BACCHIEGA, Antonio de Noronha. O cultivo da seringueira (Hevea brasiliensis) no planalto paulista noções. São José do Rio Preto: CATI, 1981. 
BONDAR, Gregório Gregorievitch. A seringueira do Pará (Hevea brasiliensis) no estado da Bahia. Salvador, Bahia: Imprensa Official do Estado, 1926

CAMARGO, Felisberto C. Considerações relativas ao problema de formação de seringais na Amazônia. Belém: Instituto Agronômico do Norte, 1943.

CAMARGO, Felisberto C. Estudo das possibilidades do desenvolvimento da cultura da seringueira no estado de São Paulo. Rio de Janeiro: Governo do Estado de São Paulo - Escritório do Estado de São Paulo - Setor da Agricultura - Rio de Janeiro, 1958.

CAMARGO, Felisberto C. Formação de seringais de cultura no estado de São Paulo. Rio de Janeiro: Escola Superior de Guerra, 1960.

CAMARGO, Felisberto C. Notas sumárias sobre a cultura da seringueira na Amazônia. Rio de Janeiro: Ministério da Agricultura - Serviço de Informação Agrícola, 1952.

CARDOSO, Mário. Nota prévia sobre a produtividade de seringueiras em São Paulo. In: SUPERINTENDÊNCIA DA BORRACHA. (ed.). SEMINÁRIO NACIONAL DA SERINGUEIRA, Rio Branco, 2., Acre, 16 a 20 de junho 1976. Anais do [...]. Rio Branco: Sudhevea, 1976.

CARDOSO, Mário. Subsidios ao desenvolvimento da heveicultura no estado de São Paulo. Campinas: [s. n.], 1979.

CATI, Coordenadoria de Assistência Técnica Integral. Plano de Expansão da Cultura da Seringueira no Estado de São Paulo. Campinas: Secretaria da Agricultura do Estado de São Paulo, 1974.

CATI, Coordenadoria de Assistência Técnica Integral. Projeto de assistência técnica à cultura da seringueira no estado de São Paulo. Campinas: Secretaria da Agricultura do Estado de São Paulo, 1975.

CATRAMBY, Guilherme. A borracha no Estado de S. Paulo - Monographia n. 15 - Exposição Nacional de Borracha de 1913. Rio de Janeiro: Republica dos Estados-Unidos do Brazil, 1913.

COHEN, Jacob. A seringueira - considerações oportunas - história de minha cooperação profissional durante 33 anos, 1910 a 1943. Belém-Pará: Instituto Histórico e Geográfico do Pará, 1945.

CORTEZ, Jayme Vasquez. Histórico e expansão da cultura da seringueira no estado de São Paulo. In: SIMPÓSIO SOBRE A CULTURA DA SERINGUEIRA NO ESTADO DE SÃO PAULO. Anais [...]. Campinas: Fundação Cargill, 1986, p. 1-10.

COUTINHO, João Martins da Silva. Breve Noticia sobre a extração da Salsa e da Seringueira: Manaus, 1863. Manaus: [s. n.], 1863.

COUTINHO, João Martins da Silva. Relatório da commissão encarregada de reconhecimento da região do oeste da Provinvia de S. Paulo e escolha da direcção mais conveniente para os transportes entre a comarca de Botucatu e o litoral pelo chefe da mesma commissão o engenheiro. Rio de Janeiro: Typographia do Diario do Rio de Janeiro, 1872.

DEAN, Warren. A luta pela borracha no Brasil: um estudo de história ecológica. São Paulo: Nobel, 1989.
DEAN, Warren. Brazil and the struggle for rubber: a study in environmental history. Cambridge; New York: Cambridge University Press, 1987. (Studies in environment and history).

DI DEUS, E. A dança das facas: trabalho e técnica em seringais paulistas. Tese (Doutorado em Antropologia) - Universidade de Brasilia, Brasilia, 2017.

DRUMMOND, José Augusto. A história ambiental: temas, fontes e linhas de pesquisa. Revista Estudos Históricos, Rio de Janeiro, v. 4, n. 8, p. 177-197, 1991.

FRANCISCO, Vera Lúcia Ferraz dos Santos; BUENO, Carlos Roberto Ferreira; FILHO, Eduardo Pires Castanho. et al. Análise comparativa da heveicultura no estado de São Paulo, 1995/96 e 2007/08. Informações Econômicas, São Paulo, v 39, n 9, p. 21-33, 2009.

GARCIA JR, Afranio. Libertos e sujeitos: sobre a transição para trabalhadores livres do nordeste. Revista Brasileira de Ciências Sociais, São Paulo, v. 3, n. 7, p. 6-41, 1988.

GARCIA JR, Afranio; HEREDIA, Beatriz Alasia de. Campesinato, familia e diversidade de explorações agrícolas no Brasil. In: GODOI, Emilia Pietrafesa de; MENEZES, Marilda Aparecida de; MARIN, Rosa Acevedo (org.). Diversidade do campesinato: expressões e categorias (Estratégias de reprodução social). São Paulo: Ed. Unesp, 2009. V. 2. p. 303-330.

GOMES, Ramonildes Alves. De sitiantes a irrigantes: construção identitária, conversão e projetos de vida. In: GODOI, Emilia Pietrafesa de; MENEZES, Marilda Aparecida de; MARIN, Rosa Acevedo (org.). Diversidade do campesinato: expressões e categorias (Estratégias de reprodução social). São Paulo: Ed. Unesp, 2009. V. 2. p. 303-330.

GONÇALVES, Paulo de Souza. Uma história de sucesso: a seringueira no Estado de São Paulo. $O$ Agronômico, Campinas, v. 54, n. 1, p. 6-14, 2002.

GRANDIN, Greg. Fordlândia: ascensão e queda da cidade esquecida de Henry Ford na selva. Rio de Janeiro: Rocco, 2010.

HOELZ, João Jacob. Cultura da seringueira. São Paulo: Secretaria da Agricultura, 1958.

HOELZ, João Jacob; MARTINEZ, Angelo Artur. A cultura da seringueira no estado de Sao Paulo. In: SUPERINTENDÊNCIA DA BORRACHA. (ed.). SEMINÁRIO NACIONAL DA SERINGUEIRA, 1. Anais do [...]. Cuiabá: Sudhevea, 1972.

HOELZ, João Jacob; STUPIELLO, J. P.; BARDAUIL, José. Cultura da seringueira - Curso de Atualização de conhecimentos agronômicos. São Paulo: Secretaria de Estado dos Negócios da Agricultura de São Paulo - Instituto Brasileiro do Café (IBC) - Grupo Executivo de Racionalização da Cafeicultura (GERCA), 1961.

HOLLOWAY, Thomas H. Imigrantes para o café: café e sociedade em São Paulo, 1886-1934. Rio de Janeiro: Paz e Terra, 1984.

IAC, Instituto Agronômico de Campinas. Carta com fotos - compra de sementes da Firestone. 
IAC, Instituto Agronômico de Campinas. Centro de Seringueira e Sistemas Agroflorestais. São Paulo, 2017. Disponivel em: http://www.iac.sp.gov.br/areasdepesquisa/seringueira/clones.php. Acesso em: 20 jun. 2017.

KRUG, Carlos Arnaldo. Relatório parcial sobre os trabalhos visando a escolha de áreas no litoral paulista destinadas ao plantio da seringueira. Campinas: Instituto Agronômico de Campinas - IAC, 1951.

KRUG, Carlos Arnaldo. Segundo Relatório parcial sobre os trabalhos visando a escolha de áreas no litoral paulista destinadas ao plantio da seringueira. Campinas: Instituto Agronômico de Campinas - IAC, 1952.

LATOUR, Bruno. Ciência em ação: como seguir cientistas e engenheiros sociedade afora. Trad. Ivone Castilho Benedetti; Jesus de Paula Assis. São Paulo: Editora UNESP, 2000

LEMONNIER, Pierre (org.). Technological choices: transformation in material cultures since the Neolithic. London; New York: Routledge, 1993. (Material cultures).

MAHL, Marcelo Lapuente. Ecologias em Terra Paulista (1894-1950): as relações entre o homem e o meio ambiente durante a expansão agrícola do Estado de São Paulo. Faculdade de Ciências e Letras - Universidade Estadual Paulista, Assis, 2007.

MARTINELLO, Pedro. A "batalha da borracha" na Segunda Guerra Mundial e suas conseqüências par o vale amazônico. Rio Branco: Ed. da Universidade Federal do Acre, 1988.

MARTINEZ, Angelo Artur. Borracha: São Paulo é o maior produtor nacional. 2006. Disponivel em: http:// www.infobibos.com/artigos. Acesso em: 07 ago. 2013

MARTINEZ, Angelo Artur. Técnica da sangria da seringueira. Suplemento Agricola - Jornal O Estado de São Paulo, 845. ed., p. 12-12, 1971.

MARTINS, José de Souza. O cativeiro da terra. São Paulo: Ed. Contexto, 2010.

MELO, Beatriz Medeiros de. História e memória na contramão da expansão canavieira: um estudo das formas de resistência dos sitiantes do extremo noroeste paulista. Tese (Doutorado em Sociologia) -- Universidade Federal de São Carlos, São Carlos, 2013.

MILLIET, Sergio. Roteiro do café e outros ensaios: contribuições para a história econômica e social do Brasil. São Paulo: Repartição de cultura, 1941 [1938].

MONBEIG, Pierre. Pioneiros e fazendeiros de São Paulo. São Paulo: Hucitec, 1984.

PAES DE CAMARGO, Ângelo. Regiões climaticamente favoráveis à seringueira no Brasil. In: HOELZ, João Jacob (ed.). Cultura da seringueira. São Paulo: Secretaria da Agricultura, 1958. p. 1-12.

ROGERS, Everett M. Key concepts and models. In: SOLO, Robert A.; ROGERS, Everett M. (ed.). Inducing technological change for economic growth and development. Michigan State University Press: [s. n.], 1972.
ROSS, Jurandyr Luciano Sanches; MOROZ, Isabel Cristina. Mapa geomorfológico do Estado de São Paulo. São Paulo: USP, FFLCH IPT FAPESP, 1997. https://doi.org/10.7154/RDG.1996.0010.0004

SAA-SP, Secretaria de Agricultura e Abastecimento de São Paulo. Programa Estadual da Seringueira. Campinas: Secretaria de Agricultura e Abastecimento de São Paulo SAA-SP, 1986.

SAUTCHUK, C. E. (ed.). Técnica e transformação: perspectivas antropológicas. Rio de Janeiro: ABA Publicações, 2017. 500 p.

SAUTCHUK, C. E.; SAUTCHUK, J. M. M. Enfrentando poetas, perseguindo peixes: sobre etnografias e engajamentos. Mana, Rio de Janeiro, v. 20, n. 3, p. 575-602, dez. 2014. https://doi.org/10.1590/S010493132014000300006

SCHWARCZ, Lilia Moritz. O espetáculo das raças: cientistas, instituições e questão racial no Brasil (1870-1930). São Paulo: Companhia das Letras, 1993

SOMAIN, René: DROULERS, Martine. A seringueira agora é paulista. Confins [On-line], n. 27, 2016. https:// doi.org/10.4000/confins.10906

SPISP (Sociedade Promotora de Immigração de São Paulo). Mappa da Provincia de São Paulo mandado organisar pela Sociedade Promotora de Immigração de S. Paulo. 1: 2.000.000, 1886. Disponivel em: https://pt.wikipedia.org/wiki/Ficheiro:Mappa_della_ Provincia_di_S._Paolo.jpg

STOLCKE, Verena. Cafeicultura: homens, mulheres e capital (1850-1980). São Paulo: Brasiliense, 1986.

WACQÜANT, L. Corpo e alma: notas etnográficas de um aprendiz de boxe. Rio de Janeiro: Relume-Dumará, 2002.

WORSTER, Donald. Para fazer história ambiental. Revista Estudos Históricos, Rio de Janeiro, v. 4, n. 8, p. 198-215, 1991.

\section{Eduardo Di Deus}

Doutor em Antropologia Social pela Universidade de Brasilia (UnB, Brasilia, DF, Brasil). Professor Adjunto da Faculdade de Educação da Universidade de Brasilia (FE/UnB); Brasilia, DF, Brasil.

\section{Endereço para correspondência}

Eduardo di Deus

Faculdade de Educação. FE-03 BSS-11/4

Campus Universitário Darcy Ribeiro

Asa Norte 70.910-900

Brasilia, DF, Brasil 